\title{
Modelagem da composição química do leite através de indicadores metabólicos em vacas leiteiras de alta produção*
}

\author{
RÔMULO CAMPOS GAONA
}

Félix Hilário Díaz González (Orientador - UFRGS)

Banca: Luis Barros (Universidad da República, Uruguai), Marcelo da Silva Cecim (UFSM), João Walter Dürr (UPF)

A lactação é um processo fisiológico complexo. Inúmeros fatores intervêm na síntese e secreção do leite, sendo os mais importantes a nutrição e o metabolismo endógeno dos nutrientes. A qualidade do leite é valorizada pela sua composição química e pelo conteúdo de células somáticas. No entanto, visando a comercialização do leite, as maiores mudanças e melhoras na qualidade podem ser atingidas através da manipulação da dieta dos animais, em especial em vacas leiteiras de alta produção. Avaliar os processos de absorção de alimentos, bem como o metabolismo catabólico e anabólico direcionado para a síntese do leite, têm sido uma grande preocupação na pesquisa de nutrição e bioquímica da produção animal. O principal objetivo da presente pesquisa foi gerar modelos matemáticos que pudessem explicar a participação de diferentes metabólitos sobre a composição química do leite. Neste intuito foram coletadas amostras de fluído ruminal, sangue, urina e leite de 140 vacas da raça Holandesa nas primeiras semanas de lactação e mantidas sob sistema semi-intensivo de produção e dieta controlada. Os animais foram selecionados de sistemas de produção no ecossistema do Planalto Médio de Rio Grande do Sul e foram amostrados em dois períodos climáticos críticos. No fluido ruminal foram avaliados o pH e o tempo de redução do azul de metileno. No sangue foram determinados os metabólitos: glicose, colesterol, $\beta$-hidroxibutirato (BHB), triglicerídeos, fructosamina, ácidos graxos não esterificados (NEFA), proteínas totais, albumina, globulina, uréia, creatinina, cálcio, fósforo e magnésio. As enzimas: aspartato amino transferase (AST), gama glutamil transferase (GGT) e creatina kinase (CK). Os hormônios: cortisol, insulina, triiodotironina (T3), tiroxina (T4), e leptina. Foi efetuado hemograma, para conhecer: hematócrito, hemoglobina, e contagem total e diferencial de células brancas. Na urina foram dosados: corpos cetônicos, $\mathrm{pH}$ e densidade. No leite foi determinada: proteína, gordura, lactose, sólidos totais, sólidos não gordurosos, contagem de células somáticas e uréia. Para a determinação de cada um dos metabólitos ou compostos foram usadas técnicas específicas validadas internacionalmente. Os diferentes valores obtidos constituíram os parâmetros básicos de entrada para a construção dos diversos modelos matemáticos executados para predizer a composição do leite. Mediante procedimentos de regressão linear múltipla algoritmo Stepwise, procedimentos de correlação linear de Pearson e procedimentos de análise computacional através de redes neurais, foram gerados diferentes modelos para identificar os parâmetros endógenos de maior relevância na predição dos diferentes componentes do leite. A parametrização das principais rotas bioquímicas, do controle endócrino, do estado de funcionamento hepático, da dinâmica ruminal e da excreção de corpos cetônicos aportou informação suficiente para predizer com diferente grau de precisão o conteúdo dos diferentes sólidos no leite.

Descritores: lactação, modelos matemáticos, composição do leite, metabolismo. 


\title{
Modeling of the chemical composition of the milk through metabolic parameteres in high yielding dairy cows ${ }^{* *}$
}

\author{
RÔMULO CAMPOS GAONA
}

\author{
Félix Hilário Díaz González (Adviser - UFRGS)
}

Committee: Luis Barros (Universidad da República, Uruguai), Marcelo da Silva Cecim (UFSM), João Walter Dürr (UPF)

The lactation is a complex physiological process. Diverse factors intervene in the synthesis and secretion of the milk, being nutrition and endogenous metabolism of the nutrients the most important. The quality of the milk is recognized greatly by the chemical composition, as by the content of somatic cells. Furthermore, the search of better quality of the milk induces that changes and advances should be reached through manipulation of the diet of the animals, especially in high yielding dairy cows. The evaluation of the food absorption processes, as well as the anabolic and catabolic metabolism for the synthesis of the milk, have been a major focus in the investigation on nutrition and biochemistry of the animal production. The main objective of this present work was to generate mathematical models that could explain the participation of different metabolites on the chemical composition of the milk. For this purpose, samples of rumenal liquid, blood, urine and milk of 140 Holstein Friesian cows were taken during the first weeks of lactation. The animals were kept in a semi-intensive production system with controlled diet and in the ecosystem of the Planalto Medium in the State of Rio Grande do Sul (Brazil.) Two critical climatic periods were evaluated. In rumenal liquid, $\mathrm{pH}$ and methylene blue reduction time were evaluated. In blood, the metabolic profile was determined and included: glucose, cholesterol, b-hydroxybutyrate (BHB), triglycerides, fructosamine, non-esterified fatty acids (NEFA), total protein, albumin, globulin, urea, creatinine, calcium, phosphorus and magnesium. Enzymes: aspartate aminotransferase (AST), gamma glutamyltransferase (GGT) and Creatine Kinase (CK). Hormones: cortisol, insulin, triiodothyronine (T3), thyroxine (T4) and leptine. In the hemogram were determined: hematocrit, hemoglobin, complete blood count and white blood cell differential. In the urine, ketonic bodies, $\mathrm{pH}$ and specific density were determined. In milk, the content of protein, fat, lactose, total solids, solids-non-fat, count of somatic cells (CCS) and urea were evaluated. The determination of each one of these metabolites or compounds was obtained by using internationally validated specific techniques. The obtained values constituted the input of basic parameters for the construction of more elaborated mathematical models to predict the milk composition. Through procedures of stepwise multiple regression, simple linear correlation (Pearson coefficient) and computational analysis through neural networks, mathematical models were generated to identify the endogenous parameters of greater relevance in the prediction of the different chemical components of the milk. The parameterization of the main biochemical routes, endocrine control, status of the liver function, rumenal dynamic and excretion of ketonic bodies provided sufficient information to predict with diverse degrees of precision the content of the different solids of the milk.

Key words: lactation, mathematical models, milk composition, metabolism. 